\title{
Microsatellite Markers to Determine Population Genetic Structure in the Golden Anchovy, Coilia dussumieri
}

\author{
A. Kathirvelpandian - A. Gopalakrishnan • \\ W. S. Lakra • Gopal Krishna • Rupam Sharma • \\ K. K. Musammilu $\cdot$ V. S. Basheer $\cdot$ J. K. Jena
}

Received: 28 March 2013/Accepted: 21 November 2013/Published online: 12 March 2014

(C) Springer Science+Business Media New York 2014

\begin{abstract}
Coilia dussumieri (Valenciennes, 1848) commonly called as golden anchovy, constitutes a considerable fishery in the northern part of both the west and east coasts of India. Despite its clear-cut geographic isolation, the species is treated as a unit stock for fishery management purposes. We evaluated 32 microsatellite primer pairs from three closely related species (resource species) belonging to the family Engraulidae through cross-species amplification in C. dussumieri. Successful cross-priming was obtained with 10 loci, which were sequenced for confirmation of repeats. Loci were tested for delineating the genetic stock structure of four populations of $C$. dussumieri from both the coasts of India. The number of alleles per locus ranged from 8 to 18 , with a mean of 12.3. Results of pairwise $F_{S T}$ indicated genetic stock structuring between the east and west coast populations of India and also validated the utilization of identified microsatellite markers in population genetic structure analysis.
\end{abstract}

\footnotetext{
A. Kathirvelpandian $(\bowtie) \cdot$ V. S. Basheer

National Bureau of Fish Genetic Resources Kochi Unit, Cochin 682 018, Kerala, India

e-mail: kathirars@gmail.com
}

\section{Present Address:}

A. Gopalakrishnan

Central Marine Fisheries Research Institute, Cochin 682 018, Kerala, India

W. S. Lakra · G. Krishna · R. Sharma

Central Institute of Fisheries Education, Mumbai 400 061, Maharashtra, India

K. K. Musammilu

Kochikkaran house, Kaipamangalam, Thrissur 682 681, Kerala, India

J. K. Jena

National Bureau of Fish Genetic Resources, Canal Ring Road, Lucknow 226 002, Uttar Pradesh, India 
Keywords Coilia dussumieri $\cdot$ Cross-species amplification · Microsatellite validation · Population genetic structure

\section{Introduction}

Marine species are generally characterized by large population sizes, high dispersion capacity during pelagic larval stages and wide biogeographic distribution. The apparent lack of migrational barriers at sea seems to guarantee a high connectivity between distant populations and precludes their allopatric subdivision (Palumbi 1992); however, the effective dispersion in the sea is still poorly understood (Hedgecock 1986). Comprehension of how such genetic discontinuities arise and evolve requires far more retrospective inference on historical biogeographic events, as well as a spatio-temporal series of population genetic data (Barton and Hewitt 1985). Detailed information on population structure and genetic diversity of these species is necessary for the formulation of effective fishery management measures in capture fisheries. The pattern of distribution of genetic variation within and between populations is referred as the genetic population structure of the species.

Coilia dussumieri (Valenciennes, 1848) constitutes an important fishery in the states of Gujarat and Maharashtra on the west coast of India, with 37,329 tons, contributing about $3.6 \%$ of total clupeid landings and $2.7 \%$ of total landings of this region. The species is caught mainly in trawl nets $(56 \%)$ and bag nets $(30 \%)$. The species also contributes considerably to the fishery in the states of West Bengal, Orissa, and Andhra Pradesh on the east coast of India (CMFRI 2012). The species is distributed on the northern part of both the east and west coasts of India, Myanmar, Thailand and Malaysia in the Indian Ocean and from Thailand to Java in the western central Pacific Ocean (Munroe and Nizinski 1999). The maximum length of the species is $217 \mathrm{~mm}$ and it has a short life span of two years. The pattern of abundance of the species coincides with that of the Bombay duck which begins in September and continues up to May. Despite its importance as a fishery, very little research has been carried out on aspects of the biology and population dynamics of the species (Fernandez and Devaraj 1996; Khan 2000).

The species posses discontinuous distribution along both the coasts of India, along with Bombay duck, which also constitutes a major fishery on the northwest coast of India. In spite of its fishery importance and peculiar distribution, $C$. dussumieri has been considered as a unit stock for fishery management purposes. The golden anchovy is one among many components exploited by the dol net, the other resources being nonpenaeid prawns, Bombay duck, unicorn cod, and juveniles of white pomfret. Given the multiple species in this fishery, it is difficult to suggest an optimum mesh size for each species (Mohan Joseph and Jayaprakash 2003). Compared with other fishes in the group, $C$. dussumieri and Bombay duck exhibit geographically isolated distribution. To avoid depletion of genetic resources of these species, sustainable management should be based on knowledge of this genetic structure; determining how units for genetically sustainable management are to be identified. Therefore, identification of the stock structure would be very useful 
in devising appropriate management regimes for sustainable utilization and conservation of these species.

Microsatellites or simple sequence repeats (SSRs) are the genetic markers widely used for identification of genetic stock structure and thereby utilized in conservation and management of fisheries. Compared with other markers, microsatellites exhibit higher levels of polymorphism and abundance in genomic DNA (Schlötterer 2000). The level of genetic diversity revealed by polymorphic microsatellite markers are much higher than those obtained with phenotypic or allozyme markers (Triantafyllidis et al. 2002; Corujo et al. 2004; Zarraonaindia et al. 2009). Despite extremely fast rate of repeat evolution, many microsatellite loci are quite conservative in their flanking regions and hence can persist largely unchanged for long evolutionary time spans. For this reason, primers developed for a species from the flanking regions of a microsatellite locus can be used to amplify the same locus in other related species. Generally, the development of new species-specific microsatellite primers is expensive and time consuming, whereas this alternative option is cheap and fast. Primers developed for a species by this method have been successfully tested for cross-species amplification on its related species in several fish species (Zardoya et al. 1996; Scribner et al. 1996; Galbusera et al. 2000; Mohindra et al. 2001; Lal et al. 2004; Gopalakrishnan et al. 2004; Langen et al. 2011). In engraulids, microsatellite loci developed in C. ectenes were successfully utilized in stock structure analysis of C. mystus (Ma et al. 2011), indicating the usefulness of novel loci for population analysis and kinship studies in anchovies. The present study was aimed at testing microsatellite primers developed in Engraulis japonicus (Chiu et al. 2002; Lin et al. 2011), E. encrasicolus (Landi et al. 2005; Pakaki et al. 2009) and Coilia ectenes (Ma et al. 2011) can provide amplification of microsatellite loci in the golden anchovy, C. dussumieri and evaluating the suitability of these microsatellite loci in genetic stock structure analysis of the species.

\section{Materials and Methods}

\section{Sample Collection and DNA Isolation}

Specimens of $C$. dussumieri were collected from the selected landing centers of Gujarat (Okha, Veraval, and Navabander) and Maharashtra (Mumbai, Ratnagiri) during November 2010-October 2011 on the west coast of India and West Bengal (Kakdwip, Kolkata) and Andhra Pradesh (Visakhapatnam, Kakinada) during January 2011-February 2012 on the east coast of India (Fig. 1). On an average, 70 specimens $(10.2-19.0 \mathrm{~cm}$ long) were collected from each of the four states during November 2010-February 2012 and the samples from each state were considered as separate populations. For DNA extraction, a piece of tissue (approx. $5 \mathrm{~g}$ of muscle) was excised just below the posterior portion of the dorsal fin and placed in $95 \%$ alcohol. Total DNA was extracted from the tissue (muscle) samples following the procedure of Miller et al. (1988) with minor modifications. The extracted DNA was checked through $0.7 \%$ agarose gel electrophoresis with 


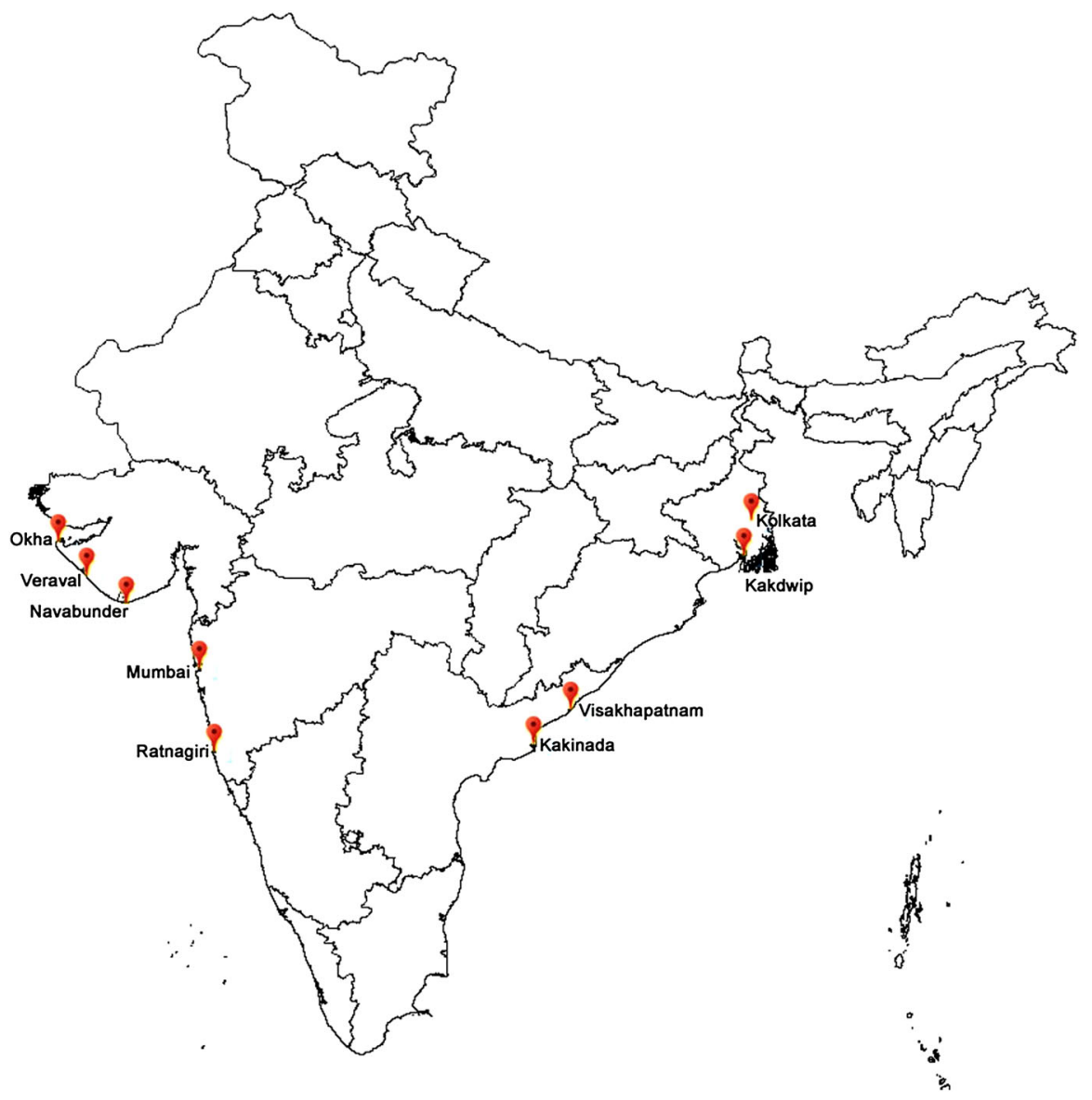

Fig. 1 Map showing sampling sites of $C$. dussumieri on the east and west coasts of India

ethidium bromide incorporated in $1 \times$ TBE buffer. The quality and quantity of the extracted DNA was checked in a UV spectrophotometer (Beckman, USA) with optical density at 260 and $280 \mathrm{~nm}$.

\section{Identification of Markers}

Available microsatellite information in the closely related species was collected from Genebank (National Center for Biotechnology Information; www.ncbi.nlm. nih.gov) and other published resources. For cross-species amplification, 32 microsatellite primers were used for screening in C. dussumieri (Table 1), with 10 primers from Engraulis japonicus (six from Chiu et al. 2002; four from Lin et al. 2011), 10 from E. encrasicolus (six from Landi et al. 2005; four from Pakaki et al. 2009) and 12 from Coilia ectenes (Ma et al. 2011). 
Table 1 Resource species microsatellite loci screened through cross-species amplification in Coilia dussumieri

\begin{tabular}{|c|c|c|c|c|}
\hline \multirow[t]{2}{*}{ Resource species } & \multirow[t]{2}{*}{ Total loci screened } & \multicolumn{3}{|l|}{ Locus } \\
\hline & & Code & Acc. No. & Amplification \\
\hline \multirow[t]{10}{*}{ Engraulis japonicus } & \multirow[t]{10}{*}{10} & EJ 2 & AF344655 & Polymorphic \\
\hline & & EJ 19 & AF344656 & Polymorphic \\
\hline & & EJ 27.1 & AF344657 & Polymorphic \\
\hline & & EJ 27.2 & AF344660 & No amplification \\
\hline & & EJ 35 & AF344658 & Polymorphic \\
\hline & & EJ 41.1 & AF344659 & No amplification \\
\hline & & EJa 17 & GU214184 & Monomorphic \\
\hline & & Eja 31 & GU214189 & No amplification \\
\hline & & Enja148 & HQ259925 & No amplification \\
\hline & & Enja181 & HQ259926 & No amplification \\
\hline \multirow[t]{10}{*}{ Engraulis encrasicolus } & \multirow[t]{10}{*}{10} & Ee2-91a & FJ534732 & No amplification \\
\hline & & Ee2- 135 & FJ534738 & Polymorphic \\
\hline & & Ee2 -165 & FJ534742 & Monomorphic \\
\hline & & Ee2 -407 & FJ534751 & No amplification \\
\hline & & Ee2- 452 & FJ534754 & No amplification \\
\hline & & Ee 2 & AY241268 & Monomorphic \\
\hline & & Ee 6 & AY241270 & No amplification \\
\hline & & Ee 10 & AY241273 & Monomorphic \\
\hline & & Ee 16 & AY241274 & No amplification \\
\hline & & Ee 92 & AY775730 & No amplification \\
\hline \multirow[t]{12}{*}{ Coilia ectenes } & \multirow[t]{12}{*}{12} & D 7 & FJ878813 & No amplification \\
\hline & & D 9 & FJ878814 & No amplification \\
\hline & & D 13 & FJ878815 & No amplification \\
\hline & & D 38 & FJ878816 & No amplification \\
\hline & & D 55 & FJ878817 & Polymorphic \\
\hline & & D 58 & FJ878818 & Polymorphic \\
\hline & & D 63 & FJ878819 & No amplification \\
\hline & & D 71 & FJ878820 & No amplification \\
\hline & & D 81 & FJ878821 & Polymorphic \\
\hline & & D 95 & FJ878822 & No amplification \\
\hline & & D 104 & FJ878824 & Polymorphic \\
\hline & & D 114 & FJ878825 & Polymorphic \\
\hline
\end{tabular}

\section{PCR Amplification and Genotyping}

The PCR was carried out in a thermal cycler (Applied Biosystems) employing the microsatellite primers. Amplifications were performed in a $25 \mu \mathrm{L}$ reaction mixture containing $1 \times$ reaction buffer $(10 \mathrm{mM}$ Tris, $50 \mathrm{mM} \mathrm{KCl}, 0.01 \%$ gelatin, $\mathrm{pH} 9.0)$ with $1.5 \mathrm{mM} \mathrm{MgCl}_{2}$ (Genei, Bangalore, India), 5 pmol each primer, $200 \mathrm{mM}$ 
dNTPs, 2 U Taq DNA polymerase (Genei, Bangalore, India), and 25-50 ng template DNA. The reaction mixture was preheated at $94^{\circ} \mathrm{C}$ for $5 \mathrm{~min}$, followed by 25 cycles of $94^{\circ} \mathrm{C}$ for $30 \mathrm{~s}$, annealing temperature (Table 2) for $45 \mathrm{~s}$, and extension at $72^{\circ} \mathrm{C}$ for $1 \mathrm{~min}$, with a final extension at $72^{\circ} \mathrm{C}$ for $5 \mathrm{~min}$. The amplified products were checked in $10 \%$ polyacrylamide gel electrophoresis (PAGE). Silver staining was used to resolve the PCR product for further genotyping and analysis. Molecular weights of the bands were calculated with reference to the molecular weight marker ( $p$ BR322 with MspI digest) using Image Lab 4.0 software in the Gel Doc system (Bio-Rad, Molecular Imager, Gel Doc XR). The PCR products of the microsatellite loci were sequenced using ABI 3730 DNA sequencer (Applied Biosystems) to confirm the occurrence of the repeat units in the amplified products. We amplified 70 samples each from four populations for all 10 selected loci and genotyped them for population genetic analysis.

\section{Genetic Variability Analysis}

Measures of genetic variation in microsatellite loci, including the number of alleles and allele frequencies at each locus, were calculated using Genepop version 3.3d (Raymond and Rousset 1998). The mean number of alleles per locus, observed and expected heterozygosities $\left(H_{\mathrm{ob}}\right.$ and $\left.H_{\mathrm{ex}}\right)$ and percentage of polymorphic loci for overall and each population were also calculated using Genepop software.

Exact $P$ tests for conformity to Hardy-Weinberg equilibrium (probability and score test) were performed by the Markov Chain method using Genepop version 3.3d (Raymond and Rousset 1998) with dememorization $=1,000$, batches $=10$, and iterations $=100$, based on a null hypothesis of random union of gametes. The significant criteria were adjusted for the number of simultaneous tests using the sequential Bonferroni technique (Rice 1989).

Presence of null alleles was tested to rule out false homozygotes. The expected frequency of null alleles was calculated using Micro-Checker 2.2.3 (Van Oosterhout et al. 2004) and all the genotypes of the loci showing deviation from HardyWeinberg equilibrium were tested for null alleles.

\section{Estimates of Population Differentiation}

Although an exact test of genotype and allele frequencies may be the most sensitive detector of population differentiation, it provides no estimate of the magnitude of the differences (Donnelly et al. 1999); hence, to assess the population structure in a quantitative way, $F_{S T}$ estimator was used. The coefficient of genetic differentiation $\left(F_{S T}\right)$ and the inbreeding coefficient $\left(F_{I S}\right)$ were estimated through the estimator of Weir and Cockerham (1984) using Genepop. This program performs numerical resampling by bootstrapping (1,000 times in the present study) and jack-knife procedures in order to estimate confidence intervals and the significance of the values.

$F_{I S}$ refers to the Hardy-Weinberg distribution of genotypes of individuals within a subpopulation and is defined as the correlation between homologous alleles within the individuals with reference to the local population. It is a measure of deviation 


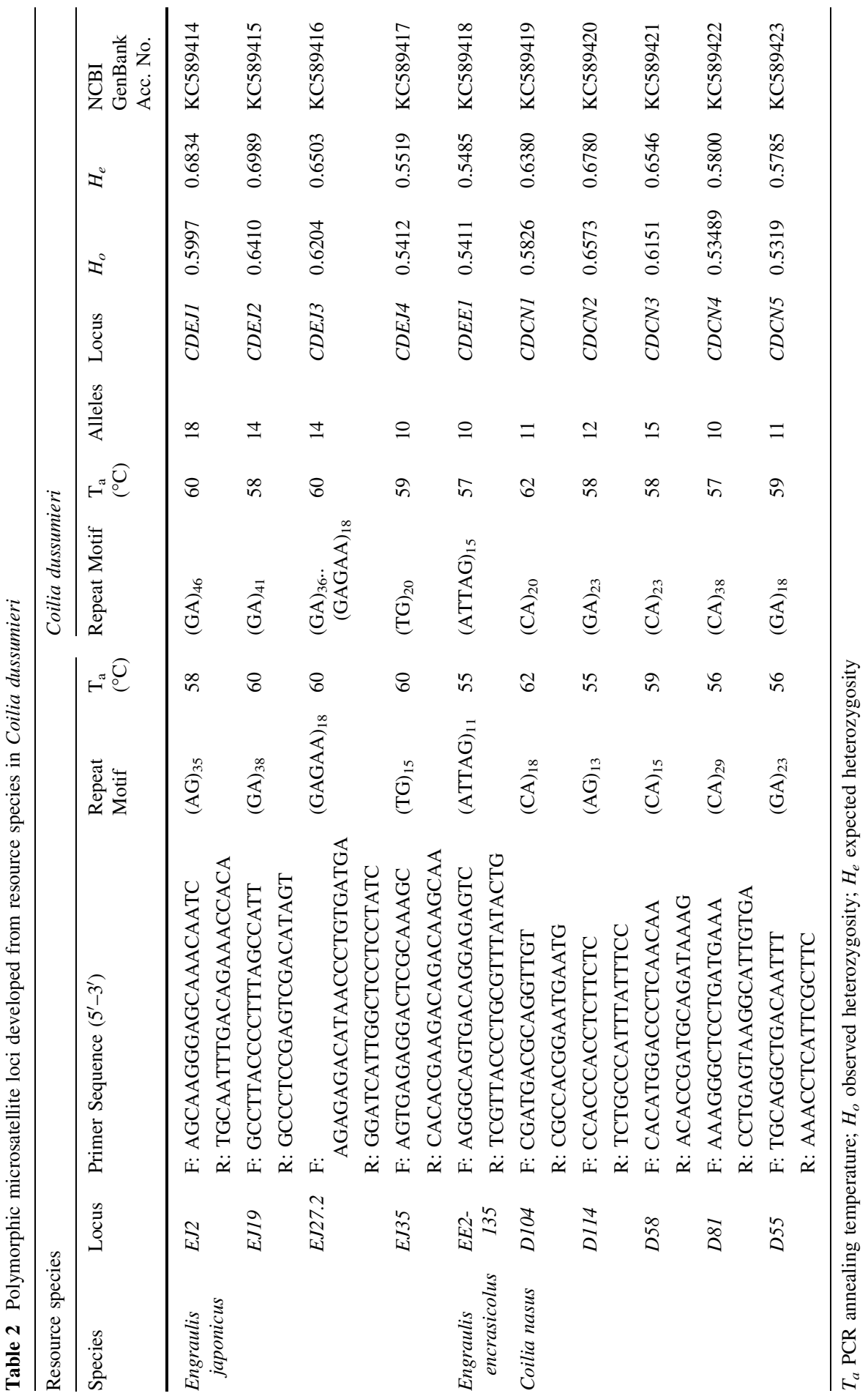


from Hardy-Weinberg proportions within samples and is sometimes known as the fixation index. Positive values demonstrate an excess of homozygotes (positive correlation between homologous allele) or conversely, a deficiency of heterozygotes, relative to the Hardy-Weinberg model. This could be due to inbreeding and this index is often labeled an inbreeding coefficient.

An analysis of molecular variance (AMOVA) to examine the amount of genetic variation partitioned within and among populations was carried out using Arlequin version 3.0 (Excoffier et al. 2005). All the individuals collected from the different sampling sites of each state were treated as a single population. Samples collected from one coast (east or west) were considered a separate group for analysis. This analysis was performed for three hierarchical groupings of the data. The first level compared genetic structure between populations of each group. The second level examined the variation among individuals within each population. Finally, variation among the populations was determined by combining all geographic samples.

\section{Results and Discussion}

For population genetic analysis, cross-species amplification has been a useful tool to identify sets of markers without developing specific primers for each study species (Galbusera et al. 2000). Out of 32 loci tried, successful cross-priming was obtained with 14 primer pairs; 10 loci were polymorphic and ideal for use as markers in stock identification studies (Table 2). Sequencing of amplified products revealed the presence of repeat motifs (acc. nos. KC589414- KC589423).

The optimum annealing temperature to produce scorable bands in C. dussumieri was slightly different from that reported for the respective primer pair in the resource species. Zardoya et al. (1996) and Galbusera et al. (2000) also reported the necessity of optimization of PCR conditions for the study species in crossamplification tests. Cross-species amplification of primers of the order Clupeiformes and family Engraulidae in $C$. dussumieri has shown evidence of remarkable evolutionary conservation of microsatellite flanking regions. In Engraulids, microsatellite loci were developed successfully in $C$. ectenes and amplified in the related species C. mystus (Ma et al. 2011). Zardoya et al. (1996) also reported that homologous microsatellite loci could persist for about 300 million years in turtle and fish and their flanking regions are highly conserved; supporting the findings of the present study. Amplification success in a species belonging to the same genus as the target species is normally high (Wilson et al. 2004). The number of amplified loci tends to decrease with increasing divergence between species (Moore et al. 1991; Peakall et al. 1998). The results obtained in the present study exhibited the similar trend that the percentage of amplification was higher in the case of the source species belonging to the same genus compared with species from a different genus.

Of the ten amplified loci, four were perfect, five were imperfect and the remaining one was complex in nature. Eight loci were found to possess dinucleotide repeat sequences, one locus contained a penta-nucleotide repeat and the remaining one possessed combinations of di and penta-nucleotide repeats ranging in 
length from 18 (CDCN5) to 46 (CDEJ1), with an average length of 29.8. The number of alleles at different microsatellite loci in $C$. dussumieri varied from 8 to 18 , with an average value of 12.3. High microsatellite allele variation was recorded in Thai silver barb (Puntius gonionotus) with an average of 13.8 alleles per locus (Kamonrat 1996) and in a number of marine fishes such as whiting (14-23 alleles/ locus; Rico et al. 1997) and Atlantic cod (8-46 alleles/locus; Bentzen et al. 1996). In anchovies, a high number of alleles was observed in E. encrasicolus (8-28, Pakaki et al. 2009; 16-43, Zarraonaindia et al. 2009); in E. japonicus (6-31, Lin et al. 2011); and in C. nasus (8-20, Yang et al. 2011). Low levels of variation was observed in C. ectenes (2-7, Ma et al. 2011) and C. mystus (3-8, Yang et al. 2011), mainly due to the low sample size used for the study (Galbusera et al. 1996). The mean observed number of alleles at each locus (12.30) in C. dussumieri was higher than that observed by Ma et al. (2011) in C. ectenes (6.5) and by Yang et al. (2011) in C. mystus (6.1). Similar results were also reported by Han et al. (2000) in striped bass (Morone saxatilis), Scribner et al. (1996) in Chinook salmon (Oncorhynchus tshawytscha), Zhang et al. (2006) in Lutjanus argentimaculatus (8.4) and in many other teleosts (Reilly and Ward 1998; McGowan and Reith 1999; Supungul et al. 2000; Iyengar et al. 2000). However, a higher value of allele number observed in the present study was in accordance with the reports in E. japonicus (17.8) by Lin et al. (2011) and (25.5) by Yu et al. (2002) and in Clarias batrachus (9.8) by Volckaert et al. (1999).

Heterozygosity across the 10 loci for all the four populations ranged from 0.4074 to 0.7465 (observed), with a mean of 0.5880 , and 0.4082 to 0.7880 (expected), with a mean of 0.6255 . The probability test revealed that the observed allele frequencies in most of the loci did not show significant deviation $(P<0.05)$ from HardyWeinberg equilibrium, except for CDEJ1, CDEJ2, CDCN4 and CDCN5 in the Gujarat population; CDEJ1, CDEJ3, CDEE1 and CDCN2 in the Maharashtra population; CDEJ4 and CDCN2 in the West Bengal population; CDEJ2, CDEJ4 and CDCN2 in the Andhra Pradesh population after sequential Bonferroni correction was made to the probability levels. Wright's (1978) fixation index $\left(F_{I S}\right)$ is a measure of heterozygote deficiency or excess (inbreeding coefficient) and was found to be significant for each locus in four populations. The values ranged from -0.0768 for the locus CDCN1 in the West Bengal population to +0.4312 for the locus CDCN2 in the Andhra Pradesh population (Table 3). In most of the loci, the value of $F_{I S}$ was found to deviate significantly from zero, indicating a deficiency of heterozygotes.

Deviation from Hardy-Weinberg is usually attributed to null alleles (Gopalakrishnan et al. 2004; Garcia de Leon et al. 1995), selection (Garcia de Leon et al. 1995), grouping of gene pools (Walhund effect; Gibbs et al. 1997), inbreeding or nonrandom mating (Beaumont and Hoare 2003). Nine of the ten primer pairs in $C$. dussumieri indicated positive $F_{I S}$ values in different populations. The expected frequency of null alleles was calculated using Micro-Checker and all the genotypes of the loci showing deviation from Hardy-Weinberg equilibrium $\left(+F_{I S}\right)$ were tested for null alleles. The estimated null allele frequency was not significant $(P<0.05)$ at all nine tested loci using different algorithms, indicating the absence of null alleles and false homozygotes. There was also a general excess of homozygotes over most of the allele size classes in all nine loci in the four populations. Therefore, the 
Table 3 Inbreeding coefficient $\left(F_{I S}\right)$ of ten microsatellite loci used for population structure analysis in Coilia dussumieri

\begin{tabular}{lcccc}
\hline \multirow{2}{*}{ Locus } & \multicolumn{4}{l}{ Population (number of samples) } \\
\cline { 2 - 5 } & Gujarat (70) & Maharashtra (70) & West Bengal (70) & Andhra Pradesh (70) \\
\hline CDEJ1 & 0.2892 & 0.2241 & 0.0030 & 0.0028 \\
CDEJ2 & 0.3378 & 0.0040 & 0.0067 & 0.1621 \\
CDEJ3 & -0.0280 & 0.2178 & 0.0024 & 0.0032 \\
CDEJ4 & 0.0014 & 0.0025 & 0.0038 & 0.1043 \\
CDEE1 & 0.0125 & 0.2134 & 0.2796 & 0.0008 \\
CDCN1 & 0.0012 & -0.0248 & -0.0768 & 0.0025 \\
CDCN2 & -0.0009 & 0.2018 & 0.0006 & 0.4312 \\
CDCN3 & 0.2024 & 0.0651 & 0.0004 & 0.0001 \\
CDCN4 & 0.1972 & 0.0643 & -0.0104 & -0.0028 \\
CDCN5 & 0.1724 & 0.0007 & 0.0098 & 0.0765 \\
\hline
\end{tabular}

possibility of heterozygote deficiency due to null alleles could be ruled out. Overexploitation may lead to reduction in effective population size of fish species across the world. Due to this, inbreeding can happen which might result in a deficiency of heterozygotes and deviation from Hardy-Weinberg equilibrium (Beaumont and Hoare 2003). This may be the cause of deficiency of heterozygotes in C. dussumieri, as reduction in landings of the species along with Bombay duck had been reported in Indian waters (Mohan Joseph and Jayaprakash 2003). A similar situation was reported in other fishes that showed decline in catches due to overexploitation (Rico et al. 1997; O'Connell et al. 1998; Beacham and Dempson 1998; Scribner et al. 1996; Yue et al. 2000; Gopalakrishnan et al. 2004).

Pairwise $F_{S T}$ estimates between populations differed significantly $(P<0.0001)$ from zero for all pairs at the four locations. The coefficient of genetic differentiation ranged from 0.0032 (between Andhra Pradesh and West Bengal) to 0.4843 (between Maharashtra and Andhra Pradesh). Significantly higher $F_{S T}$ values were observed between the west and east coast populations of India, varying from 0.4001 (West Bengal and Maharashtra) to 0.4843 (Andhra Pradesh and Maharashtra); the values among populations within the same group were comparatively lower and not significant (Table 4). The results clearly indicated genetic stock structure between C. dussumieri populations of the east and west coasts in Indian waters. The higher rates of mutation (and therefore polymorphism) of DNA markers result in greater power for population differentiation (Rousset and Raymond 1995; Goudet et al. 1996). Levels of genetic differentiation demonstrated here for golden anchovy were higher than those significant values seen in Pacific herring $\left(F_{S T}=0.023\right)$, Atlantic herring $\left(F_{S T}=0.035\right)$, and widespread anadromous fish like Atlantic salmon $\left(F_{S T}=0.054\right.$; McConnell et al. 1997), where there was no genetic differentiation observed among populations. The high $F_{S T}$ values of this study are similar to those reported in other fish species (Cook et al. 2002; Liao et al. 2006) that revealed high and significant levels of genetic structure. The AMOVA based on microsatellite data also indicated significant genetic differentiation among C. dussumieri populations 
Table 4 Pairwise Fisher's $F_{S T}(\theta)$ between samples of Coilia dussumieri using microsatellite markers

\begin{tabular}{llll}
\hline Population & Gujarat & Maharashtra & West Bengal \\
\hline Maharashtra & 0.0104 & - & - \\
West Bengal & $0.4318^{*}$ & $0.4001^{*}$ & - \\
Andhra Pradesh & $0.4516^{*}$ & $0.4843^{*}$ & 0.0032 \\
\hline
\end{tabular}

* Significant after Bonferroni adjustment $(P<0.0001)$

$\left(F_{S T}=0.4482 ; P<0.0001\right)$. The value $(65.68 \%)$ was observed among groups (east and west coast), whereas $1.08 \%$ variation was observed between populations within the group. The genetic differentiation exhibited by pairwise $F_{S T}$ was in concordance with the results of AMOVA analysis. The genetic differentiation may be explained with no or low levels of migration among the populations of both coasts of India. This in turn might have caused geographic structuring with little or low gene flow between both coasts, leading to some degree of reproductive isolation of $C$. dussumieri populations on the west and east coasts of India.

In the marine environment, currents can be circuitous, and oceanographic features like eddies and fronts can prevent mixing and diffusion of pelagic larvae, decoupling pelagic larval dispersal from Euclidean distance (Weersing and Toonen 2009). Two adjacent sites may rarely exchange migrants if located on different sides of an oceanographic front (Gilg and Hilbish 2003). This concept is well suited for the discontinuous distribution of $C$. dussumieri in Indian waters. Similar results were obtained in wreck fish (Polyprion americanus) populations of the north and south Atlantic (Sedberry et al. 1996). In anchovies, Yu et al. (2002) identified two separate stocks of Japanese anchovy (E. japonicus) in the northern and southern parts of the Taiwan Strait in the Pacific Ocean.

In conclusion, the analysis using novel hypervariable microsatellite loci in $C$. dussumieri revealed significant results. First, the potential use of heterologous PCR primers was explored and many of them appeared to be conserved in this engraulid fish species (Order Clupeiformes). Second, the utility of these markers for population genetic analyses was confirmed. All 10 amplified microsatellite loci were polymorphic and showed heterogeneity in allele frequency for the four populations. Third, the study suggested that coast-specific populations that are divergent in their genetic characteristics can be identified through microsatellite loci. The information generated will be helpful in planning strategies for the conservation and management of stocks of $C$. dussumieri in Indian waters.

Acknowledgments The authors acknowledge Director, National Bureau of Fish Genetic Resources (Indian Council of Agricultural Research), Lucknow for providing all the support and facilities for carrying out this work. The help rendered by Mr. Raj Kumar, Ms. Mohita and Ms. Linu is duly acknowledged.

\section{References}

Barton NH, Hewitt GM (1985) Analysis of hybrid zones. Annu Rev Ecol Syst 16:113-148 Beacham TD, Dempson J (1998) Population structure of Atlantic salmon from the Conne River, Newfoundland as determined from microsatellite DNA. J Fish Biol 52:665-676 
Beaumont AR, Hoare K (2003) Biotechnology and genetics in fisheries and aquaculture. Blackwell Publishing Co., Malden 158 pp

Bentzen P, Taggart CT, Ruzzante DE, Cook D (1996) Microsatellite polymorphism and the population structure of Atlantic cod (Gadus morhua) in the northwest Atlantic. Can J Fish Aquat Sci 53:2706-2721

Chiu TS, Lee YJ, Huang SW, Yu HT (2002) Polymorphic microsatellite markers for stock identification in Japanese anchovy (Engraulis japonicus). Mol Ecol Notes 2:49-50

CMFRI (2012) Annual report 2011-2012. Central Marine Fisheries Research Institute, Cochin

Cook BD, Bunn SE, Hughes JM (2002) Genetic structure and dispersal of Macrobrachium australiense (Decapoda: Palaemonidae) in Western Queensland, Australia. Freshw Biol 47(11):2098-2112

Corujo M, Blanco G, Vazquez E, Sanchez JA (2004) Genetic structure of northwestern Spanish brown trout (Salmo trutta L.) populations, differences between microsatellite and allozyme loci. Hereditas 141:258-271

Donnelly MJ, Cuamba N, Charlwood JD, Collins FH, Townson H (1999) Population structure in the malaria vector, Anopheles arabiensis Patton, in East Africa. Heredity 83:408-417

Excoffier L, Laval G, Schneider S (2005) Arlequin (version 3.0): an integrated software package for population genetics data analysis. Evol Bioinform Online 1:47-50

Fernandez I, Devaraj M (1996) Dynamics of the gold spotted grenadier anchovy (Coilia dussumieri) stock along the northwest coast of India. Indian J Fish 43(1):27-38

Galbusera P, Volckaert F, Hellemans BA, Ollevier F (1996) Isolation and characterization of microsatellite markers in the African catfish, Clarias gariepinus (Burchell, 1822). Mol Ecol 5:703-705

Galbusera P, Van S, Matthysen E (2000) Cross-species amplification of microsatellite primers in passerine birds. Conserv Genet 1:163-168

Garcia De Leon FJ, Dallas JF, Chatain B, Canonne M, Versini JJ, Bonhomme F (1995) Development and use of microsatellite marks in sea bass, Dicentrarchus labrax (Linneaus, 1758) (Perciformes: Serranidae). Mol Mar Biol Biotech 4:62-68

Gibbs HL, Prior KA, Weatherhead PJ, Johnson G (1997) Genetic structure of populations of the threatened eastern massasuaga rattlesnake, Sistrurus catenatus: evidence from microsatellite DNA markers. Mol Ecol 6:1123-1132

Gilg MR, Hilbish TJ (2003) The geography of marine larval dispersal: coupling genetics with fine-scale physical oceanography. Ecology 84:2989-2998

Gopalakrishnan A, Musammilu KK, Muneer PMA, Lal KK, Kapoor D, Ponniah AG, Mohindra V (2004) Microsatellite DNA markers to assess population structure of red-tailed barb, Gonoproktopterus ситтиса. Acta Zoologica Sinica 50(4):686-690

Goudet J, Raymond M, Meeüs T, Rousset F (1996) Testing differentiation in diploid populations. Genetics 144:1933-1940

Han K, Li Leclerc GM, Hays AM, Ely B (2000) Isolation and characterization of microsatellite loci for striped bass (Morone saxatilis). Mar Biotech 2:405-408

Hedgecock D (1986) Is gene flow from pelagic larval dispersal important in the adaptation and evolution of marine invertebrates? Bull Mar Sci 39:550-565

Iyengar A, Piyapattanakorn S, Stone DM, Heipel DA, Howell BR, Baynes SM, Maclean N (2000) Identification of microsatellite repeats in turbot (Scophthalmus maximus) and dover sole (Solea solea) using a RAPD-based technique: characterization of microsatellite markers in dover sole. Mar Biotech 2:49-56

Kamonrat W (1996) Spatial genetic structure of Thai silver barb Puntius gonionotus (Bleeker) populations in Thailand. Ph.D. Thesis, Dalhousie University, Canada, pp 11-93

Khan MZ (2000) Fishery, biology and resource characteristics of golden anchovy, Coilia dussumieri (Cuv. \& Val.). In: Pillai VN, Menon NG (eds) Marine fisheries research and management. Central Marine Fisheries Research Institute, Cochin, pp 310-316

Lal KK, Chauhan T, Mandal A, Singh RK, Khulbe L, Ponniah AG, Mohindra V (2004) Identification of microsatellite DNA markers for population structure analysis in Indian major carp, Cirrhinus mrigala (Hamilton-Buchanan, 1882). J Appl Ichthyol 20(2):87-91

Landi M, Garoia F, Piccinetti C, Tinti F (2005) Isolation of polymorphic microsatellite loci from the European anchovy, Engraulis encrasicolus. Mol Ecol Notes 5:266-268

Langen K, Schwarzer J, Kullmann H, Bakker TCM, Thünken T (2011) microsatellite support for active inbreeding in a cichlid fish. PLoS ONE 6(9):e24689. doi:10.1371/journal.pone.0024689 
Liao X, Yu X, Tong J (2006) Genetic diversity of common carp from two largest Chinese lakes and the Yangtze River revealed by microsatellite markers. Hydrobiologia 568:445-453

Lin L, Zhu L, Liu SF, Su YQ, Zhuang ZM (2011) Polymorphic microsatellite loci for the Japanese anchovy Engraulis japonicus (Engraulidae). Genet Mol Res 10(2):764-768

Ma C, Cheng Qiqun, Zhang Qingyi (2011) Development of 12 polymorphic microsatellite markers in Coilia ectenes Jordan and Seale, 1905 (Clupeiformes: Engraulidae) and cross-species amplification in Coilia mystus Linnaeus, 1758. Environ Biol Fish 91:243-249

McConnell SK, O’Reilly P, Hamilton L, Wright JM, Bentzen P (1997) Polymorphic microsatellite markers loci from Atlantic salmon (Salmo salar): genetic differentiation of North American and European populations. Can J Fish Aquat Sci 52:1862-1873

McGowan C, Reith ME (1999) Polymorphic microsatellite markers for Atlantic halibut, Hippoglossus hippoglossus. Mol Ecol 8:1761-1763

Miller SA, Dykes DD, Polesky HF (1988) A simple salting out procedure for extracting DNA from human nucleated cells. Nucl Acids Res 16(3):1215

Mohan Joseph M, Jayaprakash AA (eds) (2003) Status of exploited marine fishery resources of India. Central Marine Fisheries Research Institute, Kochi, pp 41-45

Mohindra V, Mishra A, Palanichamy M, Ponniah AG (2001) Cross-species amplification of Catla catla microsatellite locus in Labeo rohita. Indian J Fish 48(1):103-108

Moore SS, Sargeant LL, King TJ (1991) Conservation of dinucleotide microsatellites among mammalian genomes allows the use of heterologous PCR primer pairs in closely related species. Genomics 10:654-660

Munroe TA, Nizinski M (1999) Engraulidae, anchovies. PP 1698-1706 in Carpenter KE, Niem VH (eds), FAO species identification guide for fishery purposes. The living marine resources of the WCP vol. 3: Batoid fishes, chimaeras and bony fishes part 1 (Elopidae to Linophrynidae). FAO, Rome

O'Connell M, Dillon MC, Wright JM, Bentzen P, Merkouris S, Seeb J (1998) Genetic structuring among Alaskan Pacific herring populations identified using microsatellite variation. J Fish Biol 53:150-163

Pakaki V, Magoulas A, Kasapidis P (2009) New polymorphic microsatellite loci for population studies in the European anchovy, Engraulis encrasicolus. Mol Ecol Resour 9:1406-1409

Palumbi SR (1992) Marine speciation on a small planet. Trends Ecol Evol 7:114-118

Peakall R, Gilmore S, Keys W, Morgante M, Rafalski A (1998) Cross-species amplification of soybean (Glycine max) simple sequence repeats within the genus and other legume genera: implications for the transferability of SSRs in plants. Mol Biol Evol 15:1275-1287

Raymond M, Rousset F (1998) Genepop (ver. 3.1): population genetics software for exact test and ecumenicism. J Heredity 86:248-249

Reilly A, Ward RD (1998) Microsatellite loci to determine population structure of the Patagonian toothfish, Dissoslichus eleginoides. Mol Ecol 8:1753-1768

Rice WR (1989) Analyzing tables of statistical tests. Evolution 43:223-225

Rico C, Zadworny D, Kuhnlein U, FitzGerald GJ (1993) Characterization of hypervariable micro-satellite loci in the three spine stickleback, Gasterosteus aculeatus. Mol Ecol 2:271-272

Rico C, Ibrahim KM, Hewitt GM (1997) Stock composition in North Atlantic populations of whiting using microsatellite markers. J Fish Biol 51:462-475

Rousset F, Raymond M (1995) Testing heterozygote excess and deficiency. Genetics 140:1413-1419

Schlötterer C (2000) Evolutionary dynamics of microsatellite DNA. Chromosoma 109:365-371

Scribner KT, Gust JR, Fields RL (1996) Isolation and characterization of novel salmon microsatellite loci: cross-species amplification and population genetic applications. Can J Fish Aquat Sci 53:833-841

Sedberry GR, Carlin JL, Chapman RW, Eleby B (1996) Population structure of pan-oceanic wreck fish, Polyprion americanus (Teleostei: Polyprionidae), as indicated by mtDNA variation. J Fish Biol 49(Suppl A):318-329

Supungul P, Sootanan P, Klinbunga S, Kamaonrat W, Jarayabhand P, Tassanakajon A (2000) Microsatellite polymorphism and the population structure of the black tiger shrimp (Penaeus monodon) in Thailand. Mar Biotechnol 2:339-347

Triantafyllidis A, Krieg F, Cottin C, Abatzopoulos TJ, Triantaphyllidis C, Guyomard R (2002) Genetic structure and phylogeography of European catfish (Silurus glanis) populations. Mol Ecol 11:1039-1055

Van Oosterhout C, Hutchinson WF, Wills DPM, Shipley P (2004) Micro-checker: software for identifying and correcting genotyping errors in microsatellite data. Mol Ecol Notes 4:535-538 
Volckaert FAM, Helleman BAS, Poyaud L (1999) Nine polymorphic microsatellite markers in the Southeast Asian catfishes Pangasius hypophthalmus and Clarias batrachus. Anim Genet 30:383

Weersing K, Toonen RJ (2009) Population genetics, larval dispersal, and connectivity in marine systems. Mar Ecol Prog Ser 393:1-12

Weir BS, Cockerham CC (1984) Estimating F-statistics for the analysis of population structure. Evolution 38:1358-1370

Wilson ACC, Massonnet B, Simon JC, Leterme NP (2004) Cross-species amplification of microsatellite loci in aphids: assessment and application. Mol Ecol Resour 4:104-109

Wright S (1978) Evolution and the genetics of populations, vol 4: variability within and among natural populations. University of Chicago Press, Chicago

Yang JQ, Zhou XD, Liu D, Liu ZZ, Tang WQ (2011) Isolation and characterization of microsatellite loci in the fish Coilia mystus (Clupeiformes: Engraulidae) using PCR-based isolation of microsatellite arrays. Genet Mol Res 10(3):1514-1517

Yu HT, Lee YJ, Huang SW, Chiu TS (2002) Genetic analysis of populations of Japanese anchovy (Engraulidae: Engraulis japonicus) using microsatellite DNA. Mar Biotech 4:471-479

Yue GH, Chen F, Orban L (2000) Rapid isolation and characterization of microsatellites from the genome of Asian arowana (Scleropages formosus, Osteoglossidae, Pisces). Mol Ecol 9(7):1007-1009

Zardoya R, Vollmer DM, Craddock C, Streelman JT, Karl S, Meyer A (1996) Evolutionary conservation of microsatellite flanking regions and their use in resolving the phylogeny of cichlid fishes (Pisces: Perciformes). Proc R Soc Lond B 263:1589-1598

Zarraonaindia I, Pardo MA, Iriondo M, Manzano C, Estonba A (2009) Microsatellite variability in European anchovy (Engraulis encrasicolus) calls for further investigation of its genetic structure and biogeography. ICES J Mar Sci 66:1-7

Zhang J, Cai Z, Huang H (2006) Isolation and characterization of microsatellite loci from mangrove red snapper Lutjanus argentimaculatus. Mol Ecol Resour 6(2):408-411 